\title{
Halolamina pelagica gen. nov., sp. nov., a new member of the family Halobacteriaceae
}

Correspondence

Heng-Lin Cui

cuihenglin@sohu.com

\author{
Heng-Lin Cui, ${ }^{1}$ Xia Gao, ${ }^{1}$ Xin Yang ${ }^{1}$ and Xue-Wei $X^{2}$
}

\author{
${ }^{1}$ School of Food \& Biological Engineering, Jiangsu University, Zhenjiang 212013, PR China \\ ${ }^{2}$ Second Institute of Oceanography, State Oceanic Administration, Hangzhou 310012, PR China
}

\begin{abstract}
Two extremely halophilic archaeal strains, $\mathrm{TBN}_{2}{ }^{\top}$ and TBN49, were isolated from the Taibei marine solar saltern near Lianyungang city, Jiangsu province, China. Cells of the two strains were pleomorphic and Gram-negative and colonies were red. Strains TBN $21^{\top}$ and TBN49 were able to grow at $25-50{ }^{\circ} \mathrm{C}$ (optimum $37{ }^{\circ} \mathrm{C}$ ), at $1.4-5.1 \mathrm{M} \mathrm{NaCl}$ (optimum 3.4-3.9 M) and at $\mathrm{pH}$ 5.5-9.5 (optimum $\mathrm{pH}$ 7.0-7.5) and neither strain required $\mathrm{Mg}^{2+}$ for growth. Cells lysed in distilled water and the minimal $\mathrm{NaCl}$ concentration to prevent cell lysis was $8 \%(\mathrm{w} / \mathrm{v})$. The major polar lipids of the two strains were phosphatidic acid, phosphatidylglycerol, phosphatidylglycerol phosphate methyl ester, phosphatidylglycerol sulfate and eight glycolipids; three of these glycolipids (GL3, GL4 and GL5) were chromatographically identical to sulfated mannosyl glucosyl diether (S-DGD-1), galactosyl mannosyl glucosyl diether (TGD-1) and mannosyl glucosyl diether (DGD-1), respectively. Phylogenetic analysis revealed that strains TBN $21^{\top}$ and TBN49 formed a

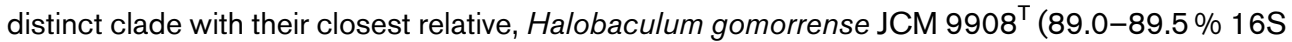
rRNA gene sequence similarity). The DNA G $+C$ contents of strains TBN $21^{\top}$ and TBN49 were 64.8 and $62.7 \mathrm{~mol} \%$, respectively. DNA-DNA hybridization between strains TBN2 ${ }^{\top}{ }^{\top}$ and TBN49 was $90.1 \%$. The phenotypic, chemotaxonomic and phylogenetic properties suggest that strains TBN $21^{\top}$ and TBN49 represent a novel species in a new genus within the family Halobacteriaceae, for which the name Halolamina pelagica gen. nov., sp. nov. is proposed. The type strain of Halolamina pelagica is TBN $21^{\top}\left(=\right.$ CGMCC $\left.1.10329^{\top}=\mathrm{JCM} 16809^{\top}\right)$.
\end{abstract}

The past 5 years have witnessed the rapid expansion of the family Halobacteriaceae, the single family described within the order Halobacteriales. As many novel species have been discovered and added to established genera (Oren et al., 2009), more and more isolates representing novel genera have been cultivated and described, such as Halovivax asiaticus (Castillo et al., 2006a), Halostagnicola larsenii (Castillo et al., 2006b), Haladaptatus paucihalophilus (Savage et al., 2007), Haloquadratum walsbyi (Burns et al., 2007), Haloplanus natans (Bardavid et al., 2007), Halopiger xanaduensis (Gutiérrez et al., 2007), Halosarcina pallida (Savage et al., 2008), Halonotius pteroides (Burns et al., 2010), Halogranum rubrum (Cui et al., 2010a), Halopelagius inordinatus (Cui et al., 2010c), Natronoarchaeum mannanilyticum (Shimane et al., 2010), Halarchaeum acidiphilum (Minegishi et al., 2010) and Halomarina oriensis (Inoue

Abbreviations: DGD, mannosyl glucosyl diether; S-DGD, sulfated mannosyl glucosyl diether; TGD, galactosyl mannosyl glucosyl diether.

The GenBank/EMBL/DDBJ accession numbers for the 16S rRNA gene sequences of strains TBN2 $1^{\top}$ and TBN49 are GU208826 and GU208827.

Three supplementary figures are available with the online version of this paper. et al., 2011). This expansion indicates that the family Halobacteriaceae is more diverse than was previously recognized. During our surveys of the halophilic archaeal diversity of marine solar salterns of eastern China, we isolated two pleomorphic, thin-slice-shaped strains that were phylogenetically related to Halobaculum ( $\mathrm{Hbl}$.) gomorrense Oren et al. 1995 (89.0-89.5\% 16S rRNA gene sequence similarity to the type strain). In this study, we characterize these two strains as representing a novel species in a new genus of the family Halobacteriaceae.

Strains $\mathrm{TBN} 21^{\mathrm{T}}$ and TBN49 were isolated from brine sampled from Taibei marine solar saltern $\left(34^{\circ} 43^{\prime} 38^{\prime \prime} \mathrm{N}\right.$ $\left.119^{\circ} 17^{\prime} 48^{\prime \prime} \mathrm{E}\right)$ near Lianyungang city of Jiangsu province, China. The neutral oligotrophic haloarchaeal medium (NOM) used for the isolation procedure contained the following $\left(1^{-1}\right)$ : $0.05 \mathrm{~g}$ yeast extract (Oxoid), $0.25 \mathrm{~g}$ fish peptone (Sinopharm Chemical Reagent Co., Ltd), $1.0 \mathrm{~g}$ sodium pyruvate, $5.4 \mathrm{~g} \mathrm{KCl}, 0.3 \mathrm{~g} \mathrm{~K}_{2} \mathrm{HPO}_{4}, 0.25 \mathrm{~g} \mathrm{CaCl}_{2}$, $0.25 \mathrm{~g} \mathrm{NH}_{4} \mathrm{Cl}, 26.8 \mathrm{~g} \mathrm{MgSO}_{4} .7 \mathrm{H}_{2} \mathrm{O}, 23.0 \mathrm{~g} \mathrm{MgCl}_{2} \cdot 6 \mathrm{H}_{2} \mathrm{O}$ and $184.0 \mathrm{~g} \mathrm{NaCl}$ (adjusted to $\mathrm{pH} 7.0-7.2$ with $1 \mathrm{M}$ $\mathrm{NaOH}$ ) (Cui et al., 2010a). The medium was solidified with $2.0 \%$ agar. The strains were routinely grown aerobically at $37{ }^{\circ} \mathrm{C}$ in NOM-3 medium (NOM series medium) with the following modifications $\left(1^{-1}\right): 1.0 \mathrm{~g}$ 
yeast extract, $0.25 \mathrm{~g}$ fish peptone, $0.25 \mathrm{~g}$ sodium formate, $0.25 \mathrm{~g}$ sodium acetate, $0.25 \mathrm{~g}$ sodium lactate and $0.25 \mathrm{~g}$ sodium pyruvate.

Phenotypic tests were performed according to the proposed minimal standards for description of new taxa in the order Halobacteriales (Oren et al., 1997). The type strains Halogranum rubrum RO2-11 ${ }^{\mathrm{T}}$, Hbl. gomorrense JCM 9908 ${ }^{\mathrm{T}}$, Halorubrum litoreum $\mathrm{Fa}-1^{\mathrm{T}}$, Halonotius (Hns.) pteroides $1.15 .5^{\mathrm{T}}$ and Haloferax volcanii CGMCC $1.2150^{\mathrm{T}}$ were selected as reference strains. Cell morphology and motility in exponentially growing liquid cultures were examined using a microscope equipped with phasecontrast optics (Nikon model E400). Minimal salt concentrations to prevent cell lysis were tested by suspending washed cells in serial sterile saline solutions containing $0-15 \%(\mathrm{w} / \mathrm{v}) \mathrm{NaCl}$ and the stability of the cells was detected by light microscopic examination.

Gram staining was performed by following the method outlined by Dussault (1955). Most biochemical and nutritional tests were performed as described and proposed by Oren et al. (1997). Briefly, growth and gas formation with nitrate as electron acceptor were tested in $9 \mathrm{ml}$ stoppered tubes completely filled with liquid NOM to which $\mathrm{NaNO}_{3}\left(5 \mathrm{~g} \mathrm{l}^{-1}\right)$ had been added and containing an inverted Durham tube. The formation of gas from nitrate was detected by the presence of gas bubbles in the Durham tubes and the formation of nitrite was monitored colorimetrically. Anaerobic growth in the presence of $\mathrm{L}$-arginine and DMSO $\left(5 \mathrm{~g} \mathrm{l}^{-1}\right)$ was tested in completely filled $9 \mathrm{ml}$ stoppered tubes. Starch hydrolysis was determined on NOM agar plates supplemented with $2 \mathrm{~g}$ soluble starch $1^{-1}$ and detected by flooding the plates with Lugol's iodine solution. Gelatin hydrolysis was performed by growing colonies on NOM agar plates amended with $1 \%(\mathrm{w} / \mathrm{v})$ gelatin and flooding the plates with Frazier's reagent (McDade \& Weaver, 1959) after growth was established. Esterase activity was detected as outlined by Gutiérrez \& González (1972). Tests for catalase and oxidase activities were performed as described by Gonzalez et al. (1978). Production of $\mathrm{H}_{2} \mathrm{~S}$ was tested by growing the isolates and reference strains in a tube with liquid NOM supplemented with $0.5 \%(\mathrm{w} / \mathrm{v})$ sodium thiosulfate; a filter-paper strip impregnated with lead acetate was used for $\mathrm{H}_{2} \mathrm{~S}$ detection (Cui et al., 2007). To test for growth on single carbon sources, fish peptone and sodium pyruvate were omitted from NOM and the compound to be tested was added at a concentration of $5 \mathrm{~g} \mathrm{l}^{-1}$. Antibiotic susceptibilities were determined by the method of Gutiérrez et al. (2008) on NOM agar plates with antibiotic discs containing the following amounts $(\mu \mathrm{g}$ per disc, unless indicated): ampicillin (10), anisomycin (20), aphidicolin (20), bacitracin (0.04 IU), chloramphenicol (30), ciprofloxacin (5), erythromycin (15), gentamicin (10), kanamycin (30), nalidixic acid (30), neomycin (30), norfloxacin (10), novobiocin (30), penicillin G (10 IU), rifampicin (5), streptomycin (10), tetracycline (30) and vancomycin (30).
Polar lipids were extracted using a chloroform/methanol system and analysed using one- and two-dimensional TLC, as described previously (Kates, 1986). Merck silica gel 60 $\mathrm{F}_{254}$ aluminium-backed thin-layer plates were used in TLC analysis. In two-dimensional TLC, the first solvent was chloroform/methanol/water $(65: 25: 4$, by vol.) and the second solvent was chloroform/methanol/acetic acid/water $(80: 12: 15: 4$, by vol.), which was also used in onedimensional TLC. All TLC plates were sprayed with sulfuric acid/ethanol $(1: 2, \mathrm{v} / \mathrm{v})$ followed by heating at $150{ }^{\circ} \mathrm{C}$ for 3 min to detect phospholipids and glycolipids.

Genomic DNA from halophilic archaeal strains was prepared as described by $\mathrm{Ng}$ et al. (1995). The 16S rRNA gene was amplified by PCR by using primers $0018 \mathrm{~F}$ and 1518R (Cui et al., 2009). PCR was performed in a thermal cycler (MJ Research PTC-150) for 30 cycles as described previously (Cui et al., 2010b). PCR products were examined on a $1.0 \%(\mathrm{w} / \mathrm{v})$ agarose gel and then cloned into the pEASY-T vector (TransGen Biotech) and transformed into Escherichia coli Mach1. Twenty transformants of each strain were picked randomly and sequenced at the SinoGenoMax Company Limited (Beijing, China) to determine whether the two strains possessed multiple distinct 16S rRNA genes. Multiple sequence alignments were performed using the CLUSTAL W program integrated in MEGA 5 software (http://www.megasoftware.net/) (Kumar et al., 2008). Phylogenetic trees were reconstructed using the neighbour-joining (Saitou \& Nei, 1987), maximum-parsimony (Fitch, 1971) and maximum-likelihood (Felsenstein, 1981) algorithms in MEGA 5 software. The percentages of replicate trees in which the associated taxa clustered together in the bootstrap test (1000 replicates) are shown next to the branches. 16S rRNA gene sequence similarity was calculated using the pairwisedistance computing function of MEGA 5 in comparison with sequences of related halophilic archaea. The DNA G $+\mathrm{C}$ content was determined by thermal denaturation method $\left(T_{\mathrm{m}}\right)$ (Marmur \& Doty, 1962). DNA-DNA hybridization analyses were performed according to the thermal denaturation and renaturation method of De Ley et al. (1970) as modified by Huß et al. (1983).

Cells of strains $\mathrm{TBN} 21^{\mathrm{T}}$ and TBN49 were non-motile and showed pleomorphic thin-slice shapes when grown in liquid NOM-3 (Supplementary Fig. S1, available in IJSEM Online). Cells stained Gram-negative and colonies were red. Strains TBN2 $1^{\mathrm{T}}$ and TBN49 were able to grow at 25$50{ }^{\circ} \mathrm{C}$ (optimum $37{ }^{\circ} \mathrm{C}$ ), 1.4-5.1 M NaCl (optimum 3.4$3.9 \mathrm{M}$ ) and $\mathrm{pH}$ 5.5-9.5 (optimum pH 7.0-7.5) and neither strain required $\mathrm{Mg}^{2+}$ for growth. Cells lysed in distilled water and the minimal $\mathrm{NaCl}$ concentration to prevent cell lysis was $8 \%(\mathrm{w} / \mathrm{v})$. Strains TBN $21^{\mathrm{T}}$ and TBN49 hydrolysed starch weakly but did not hydrolyse gelatin, Tween 80 or casein. Both strains produced $\mathrm{H}_{2} \mathrm{~S}$ from sodium thiosulfate, but did not produce indole from tryptophan. They were able to grow in defined and complex media: D-glucose, D-mannose, D-galactose, acetate, pyruvate and DL-lactate yielded the best growth as single carbon sources. 
Strain TBN49 could reduce nitrate to nitrite, but strain TBN21 could not. More detailed results of phenotypic tests and nutritional features of the two strains are given in the species description.

The polar lipids of strains $\mathrm{TBN} 21^{\mathrm{T}}$ and $\mathrm{TBN} 49$ were phosphatidic acid, phosphatidylglycerol, phosphatidylglycerol phosphate methyl ester, phosphatidylglycerol sulfate and eight glycolipids; three of these glycolipids (GL3, GL4 and GL5) were chromatographically identical to S-DGD-1 (sulfated mannosyl glucosyl diether 1), TGD-1 (galactosyl mannosyl glucosyl diether 1) and DGD-1 (mannosyl glucosyl diether 1), respectively (Supplementary Fig. S2). The glycolipid profile sets strains TBN $21^{\mathrm{T}}$ and TBN49 apart from Hbl. gomorrense, which contains S-DGD-1 and DGD-1 (Oren et al., 1995), Halogranum rubrum, which contains S-DGD-1, DGD-1 and trace unidentified glycolipids that run faster chromatographically than DGD-1 (Cui et al., 2010a), Hns. pteroides, which contains S-DGD-1 (Burns et al., 2010), and Halorubrum species, which contain S-DGD-3 (Oren et al., 2009).

Sixteen complete $16 \mathrm{~S}$ rRNA gene sequences of strain TBN $21^{\mathrm{T}}$ and 19 complete $16 \mathrm{~S}$ rRNA gene sequences of strain TBN49 were obtained. Sequence comparisons indicated that strains $\mathrm{TBN} 21^{\mathrm{T}}$ and TBN49 each contain a single 16S rRNA gene and their sequences are $99.9 \%$ similar. Both strains showed relatively low levels of $16 \mathrm{~S}$ rRNA gene sequence similarity to other members of the family Halobacteriaceae and the closest related recognized species were $\mathrm{Hbl}$. gomorrense (89.0-89.5\% similarity to the type strain), Halogranum rubrum (89.7-89.8\% similarity) and Halosarcina pallida ( $89.9 \%$ similarity). Phylogenetic analysis using the neighbour-joining algorithm revealed that strains TBN $21^{\mathrm{T}}$ and TBN49 formed a distinct clade with $\mathrm{Hbl}$. gomorrense (Fig. 1). The phylogenetic position was confirmed in trees generated using the maximumparsimony and maximum-likelihood algorithms (Supplementary Fig. S3). Phylogenetic analysis of the 16S rRNA gene revealed that the two strains represent a novel taxon.

The DNA G $+\mathrm{C}$ contents of strains TBN $21^{\mathrm{T}}$ and TBN49 were 64.8 and $62.7 \mathrm{~mol} \%$, respectively. These values are within the range of values reported for Halogranum (Cui et al., 2010a) and Halorubrum (Oren et al., 2009; Mancinelli et al., 2009) and higher than Hns. pteroides
(58 mol\%) (Burns et al., 2010), but lower than the value reported for Hbl. gomorrense (Oren et al., 1995). DNADNA hybridization between strains $\mathrm{TBN} 21^{\mathrm{T}}$ and TBN49 was $90.1 \%$, showing that the two strains should be classified in the same species, since the generally accepted threshold value to separate two species is $70 \%$ (Stackebrandt \& Goebel, 1994).

This polyphasic taxonomic study provides evidence that strains TBN21 ${ }^{\mathrm{T}}$ and TBN49 represent a novel species of a new genus within the family Halobacteriaceae, for which the name Halolamina pelagica gen. nov., sp. nov. is proposed. Characteristics that distinguish strains $\mathrm{TBN} 21^{\mathrm{T}}$ and TBN49 from members of other genera within the Halobacteriaceae are shown in Table 1.

\section{Description of Halolamina gen. nov.}

Halolamina [Ha.lo.la'mi.na. Gr. n. hals, halos salt; L. fem. n. lamina a thin slice; N.L. fem. n. Halolamina thin-sliceshaped salt (organism)].

Cells are pleomorphic and thin-slice-shaped under optimal growth conditions and stain Gram-negative. Aerobic heterotrophs. Cells lyse in distilled water. Oxidase and catalase tests are positive. Extremely halophilic, with growth occurring in media containing $1.4-5.1 \mathrm{M} \mathrm{NaCl}$; known strains grow best at 3.4-3.9 M NaCl. The optimum magnesium concentration varies between 0.01 and $0.05 \mathrm{M}$. Temperatures of $25-50{ }^{\circ} \mathrm{C}$ and $\mathrm{pH} 5.5-9.5$ support growth. Sugars are metabolized, in some cases with the formation of acids. The polar lipids are phosphatidic acid, phosphatidylglycerol, phosphatidylglycerol phosphate methyl ester, phosphatidylglycerol sulfate and eight glycolipids; three of these glycolipids are chromatographically identical to SDGD-1, TGD-1 and DGD-1. The genomic DNA G+C content is $62.7-64.8 \mathrm{~mol} \%$. Known strains have been isolated from marine solar salterns. The type species is Halolamina pelagica. Recommended three-letter abbreviation: $\mathrm{Hlm}$.

\section{Description of Halolamina pelagica sp. nov.}

Halolamina pelagica (pe.la'gi.ca. L. fem. adj. pelagica of or belonging to the sea).

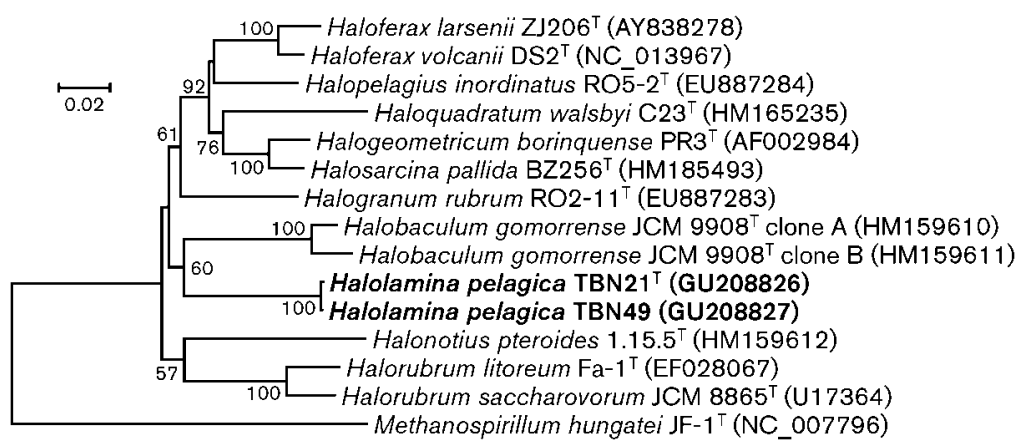

http://ijs.sgmjournals.org
Fig. 1. Neighbour-joining phylogenetic tree based on 16S rRNA gene sequences showing relationships between strains $\operatorname{TBN} 21^{\top}$ and TBN49 and close relatives within the family Halobacteriaceae. Bootstrap percentages based on 1000 replicates are shown for branches with more than $50 \%$ support. Bar, 0.02 substitutions per nucleotide position. 
Table 1. Differential characteristics between strains TBN21 ${ }^{\top}$ and TBN49 and closely related genera within the order Halobacteriales

Taxa: 1, strains TBN21 ${ }^{\mathrm{T}}$ and TBN49 (for variable data, given as TBN21 ${ }^{\mathrm{T}} / \mathrm{TBN} 49$ ); 2, Halobaculum (data from Oren et al., 1995); 3, Halogranum (Cui et al., 2010b); 4, Halorubrum (Oren et al., 2009; Mancinelli et al., 2009); 5, Halonotius (Burns et al., 2010). +, Positive; -, negative; v, positive or negative, depending on the species; w, weak; PGS, phosphatidylglycerol sulfate.

\begin{tabular}{|c|c|c|c|c|c|}
\hline Characteristic & 1 & 2 & 3 & 4 & 5 \\
\hline Cell morphology & Pleomorphic & Rod & Pleomorphic & Pleomorphic & Flat rod \\
\hline Motility & - & + & $\mathrm{v}$ & $\mathrm{v}$ & + \\
\hline $\mathrm{Mg}^{2+}$ required & - & + & $\mathrm{V}$ & $\mathrm{v}$ & - \\
\hline Reduction of nitrate to nitrite & $-1+$ & + & $\mathrm{v}$ & $\mathrm{v}$ & - \\
\hline \multicolumn{6}{|l|}{ Utilization of: } \\
\hline D-Mannose & + & - & + & $\mathrm{v}$ & - \\
\hline D-Xylose & - & + & - & $\mathrm{v}$ & - \\
\hline Maltose & - & + & $\mathrm{v}$ & $\mathrm{V}$ & - \\
\hline Sucrose & - & + & + & $\mathrm{v}$ & - \\
\hline Lactose & - & - & $+/ \mathrm{w}$ & $\mathrm{v}$ & - \\
\hline Acetate & + & - & + & $\mathrm{v}$ & - \\
\hline Pyruvate & + & - & + & $\mathrm{V}$ & + \\
\hline Presence of PGS & + & - & $\mathrm{v}$ & $\mathrm{v}$ & - \\
\hline Glycolipid(s)* & $\begin{array}{l}\text { S-DGD-1, DGD-1, } \\
\text { TGD-1, } 4 \text { UG }\end{array}$ & S-DGD-1 & $\begin{array}{c}\text { S-DGD-1, DGD-1, 2-3 } \\
\text { UG }\end{array}$ & S-DGD-3 & S-DGD-1 \\
\hline DNA G $+C$ content $(\mathrm{mol} \%)$ & $64.8 / 62.7$ & 70 & $55.7-64.0$ & $60.2-71.2$ & 58 \\
\hline
\end{tabular}

${ }^{\star} \mathrm{UG}$, Unidentified glycolipids.

Displays the following properties in addition to those described for the genus. Colonies on agar plates containing 3.4-3.9 M NaCl are red, elevated and round. Chemoorganotrophic. Growth occurs at $25-50{ }^{\circ} \mathrm{C}$ (optimum $37^{\circ} \mathrm{C}$ ), $1.4-5.1 \mathrm{M} \mathrm{NaCl}$ (optimum 3.4-3.9 M), 0-0.7 M $\mathrm{MgCl}_{2}$ (optimum 0.01-0.05 M) and $\mathrm{pH}$ 5.5-9.5 (optimum $\mathrm{pH}$ 7.0-7.5). Minimal $\mathrm{NaCl}$ concentration to prevent cell lysis is $8 \%(\mathrm{w} / \mathrm{v})$. Does not grow under anaerobic conditions with nitrate, arginine or DMSO. Nitrate reduction to nitrite is observed in some strains. $\mathrm{H}_{2} \mathrm{~S}$ is not produced from sodium thiosulfate. Indole formation is negative. Hydrolyses starch weakly but does not hydrolyse gelatin, casein or Tween 80 . The following substrates are utilized as single carbon and energy sources for growth: D-glucose, D-mannose, D-galactose, starch, acetate, pyruvate and DL-lactate. The following substrates are utilized as single carbon, nitrogen or energy sources for growth: L-alanine, L-arginine, L-glutamate and L-ornithine. No growth occurs on D-fructose, L-sorbose, D-ribose, D-xylose, maltose, sucrose, lactose, glycerol, D-mannitol, D-sorbitol, succinate, L-malate, fumarate, citrate, glycine, L-aspartate or L-lysine. Acid is produced from D-glucose, D-mannose and D-galactose. Sensitive to the following antibiotics ( $\mu \mathrm{g}$ per disc, unless indicated): novobiocin (30), bacitracin (0.04 IU), anisomycin (20), aphidicolin (20) and rifampicin (5). Resistant to erythromycin (15), penicillin G (10 IU), ampicillin (10), chloramphenicol (30), neomycin (30), norfloxacin (10), ciprofloxacin (5), streptomycin (10), kanamycin (30), tetracycline (30), vancomycin (30), gentamicin (10) and nalidixic acid (30). The DNA G+C content of the type strain is $64.8 \mathrm{~mol} \%\left(T_{\mathrm{m}}\right)$.
The type strain, TBN21 ${ }^{\mathrm{T}}\left(=\mathrm{CGMCC} 1.10329^{\mathrm{T}}=\mathrm{JCM}\right.$ $\left.16809^{\mathrm{T}}\right)$, and reference strain TBN49 (=CGMCC 1.10330 $=\mathrm{JCM} 16810)$ were isolated from Taibei marine solar saltern near Lianyungang city, Jiangsu province, China.

\section{Acknowledgements}

This work was supported by the National Natural Science Foundation of China (no. 30970006). We are grateful to Dr Mike Dyall-Smith for kindly providing strain Hns. pteroides $1.15 .5^{\mathrm{T}}$.

\section{References}

Bardavid, R. E., Mana, L. \& Oren, A. (2007). Haloplanus natans gen. nov., sp. nov., an extremely halophilic, gas-vacuolate archaeon isolated from Dead Sea-Red Sea water mixtures in experimental outdoor ponds. Int J Syst Evol Microbiol 57, 780-783.

Burns, D. G., Janssen, P. H., Itoh, T., Kamekura, M., Li, Z., Jensen, G., Rodríguez-Valera, F., Bolhuis, H. \& Dyall-Smith, M. L. (2007). Haloquadratum walsbyi gen. nov., sp. nov., the square haloarchaeon of Walsby, isolated from saltern crystallizers in Australia and Spain. Int J Syst Evol Microbiol 57, 387-392.

Burns, D. G., Janssen, P. H., Itoh, T., Kamekura, M., Echigo, A. \& Dyall-Smith, M. L. (2010). Halonotius pteroides gen. nov., sp. nov., an extremely halophilic archaeon recovered from a saltern crystallizer. Int J Syst Evol Microbiol 60, 1196-1199.

Castillo, A. M., Gutiérrez, M. C., Kamekura, M., Ma, Y.-H., Cowan, D. A., Jones, B. E., Grant, W. D. \& Ventosa, A. (2006a). Halovivax asiaticus gen. nov., sp. nov., a novel extremely halophilic archaeon isolated from Inner Mongolia, China. Int J Syst Evol Microbiol 56, 765-770.

Castillo, A. M., Gutiérrez, M. C., Kamekura, M., Xue, Y.-F., Ma, Y.-H., Cowan, D. A., Jones, B. E., Grant, W. D. \& Ventosa, A. (2006b). 
Halostagnicola larsenii gen. nov., sp. nov., an extremely halophilic archaeon from a saline lake in Inner Mongolia, China. Int J Syst Evol Microbiol 56, 1519-1524.

Cui, H.-L., Lin, Z.-Y., Dong, Y., Zhou, P.-J. \& Liu, S.-J. (2007). Halorubrum litoreum sp. nov., an extremely halophilic archaeon from a solar saltern. Int J Syst Evol Microbiol 57, 2204-2206.

Cui, H.-L., Zhou, P.-J., Oren, A. \& Liu, S.-J. (2009). Intraspecific polymorphism of $16 \mathrm{~S}$ rRNA genes in two halophilic archaeal genera, Haloarcula and Halomicrobium. Extremophiles 13, 31-37.

Cui, H.-L., Gao, X., Sun, F.-F., Dong, Y., Xu, X.-W., Zhou, Y.-G., Liu, H.-C., Oren, A. \& Zhou, P.-J. (2010a). Halogranum rubrum gen. nov., sp. nov., a halophilic archaeon isolated from a marine solar saltern. Int J Syst Evol Microbiol 60, 1366-1371.

Cui, H.-L., Gao, X., Li, X.-Y., Xu, X.-W., Zhou, Y.-G., Liu, H.-C. \& Zhou, P.-J. (2010b). Haloplanus vescus sp. nov., an extremely halophilic archaeon from a marine solar saltern, and emended description of the genus Haloplanus. Int J Syst Evol Microbiol 60, 1824-1827.

Cui, H.-L., Li, X.-Y., Gao, X., Xu, X.-W., Zhou, Y.-G., Liu, H.-C., Oren, A. \& Zhou, P.-J. (2010c). Halopelagius inordinatus gen. nov., sp. nov., a new member of the family Halobacteriaceae isolated from a marine solar saltern. Int J Syst Evol Microbiol 60, 2089-2093.

De Ley, J., Cattoir, H. \& Reynaerts, A. (1970). The quantitative measurement of DNA hybridization from renaturation rates. Eur $J$ Biochem 12, 133-142.

Dussault, H. P. (1955). An improved technique for staining red halophilic bacteria. J Bacteriol 70, 484-485.

Felsenstein, J. (1981). Evolutionary trees from DNA sequences: a maximum likelihood approach. J Mol Evol 17, 368-376.

Fitch, W. M. (1971). Toward defining the course of evolution: minimum change for a specific tree topology. Syst Zool 20, 406-416.

Gonzalez, C., Gutierrez, C. \& Ramirez, C. (1978). Halobacterium vallismortis sp. nov. An amylolytic and carbohydrate-metabolizing, extremely halophilic bacterium. Can J Microbiol 24, 710-715.

Gutiérrez, C. \& González, C. (1972). Method for simultaneous detection of proteinase and esterase activities in extremely halophilic bacteria. Appl Microbiol 24, 516-517.

Gutiérrez, M. C., Castillo, A. M., Kamekura, M., Xue, Y.-F., Ma, Y.-H., Cowan, D. A., Jones, B. E., Grant, W. D. \& Ventosa, A. (2007). Halopiger xanaduensis gen. nov., sp. nov., an extremely halophilic archaeon isolated from saline Lake Shangmatala in Inner Mongolia, China. Int J Syst Evol Microbiol 57, 1402-1407.

Gutiérrez, M. C., Castillo, A. M., Kamekura, M. \& Ventosa, A. (2008). Haloterrigena salina sp. nov., an extremely halophilic archaeon isolated from a salt lake. Int J Syst Evol Microbiol 58, 2880-2884.

Huß, V. A. R., Festl, H. \& Schleifer, K. H. (1983). Studies on the spectrophotometric determination of DNA hybridization from renaturation rates. Syst Appl Microbiol 4, 184-192.

Inoue, K., Itoh, T., Ohkuma, M. \& Kogure, K. (2011). Halomarina oriensis gen. nov., sp. nov., a halophilic archaeon isolated from a seawater aquarium. Int J Syst Evol Microbiol 61, 942-946.

Kates, M. (1986). Techniques of Lipidology, 2nd rev. edn, pp. 106-107, 241-246. Amsterdam: Elsevier.
Kumar, S., Nei, M., Dudley, J. \& Tamura, K. (2008). MEGA: a biologistcentric software for evolutionary analysis of DNA and protein sequences. Brief Bioinform 9, 299-306.

Mancinelli, R. L., Landheim, R., Sánchez-Porro, C., DornmayrPfaffenhuemer, M., Gruber, C., Legat, A., Ventosa, A., Radax, C., Ihara, K. \& other authors (2009). Halorubrum chaoviator sp. nov., a haloarchaeon isolated from sea salt in Baja California, Mexico, Western Australia and Naxos, Greece. Int J Syst Evol Microbiol 59, 1908-1913.

Marmur, J. \& Doty, P. (1962). Determination of the base composition of deoxyribonucleic acid from its thermal denaturation temperature. J Mol Biol 5, 109-118.

McDade, J. J. \& Weaver, R. H. (1959). Rapid methods for the detection of gelatin hydrolysis. J Bacteriol 77, 60-64.

Minegishi, H., Echigo, A., Nagaoka, S., Kamekura, M. \& Usami, R. (2010). Halarchaeum acidiphilum gen. nov., sp. nov., a moderately acidophilic haloarchaeon isolated from commercial solar salt. Int $J$ Syst Evol Microbiol 60, 2513-2516.

Ng, W.-L., Yang, C.-F., Halladay, J. T., Arora, A. \& DasSarma, S. (1995). Protocol 25. Isolation of genomic and plasmid DNAs from Halobacterium halobium. In Archaea: a Laboratory Manual, vol. 1, pp. 179-180. Edited by S. DasSarma \& E. M. Fleischmann. Cold Spring Harbor, NY: Cold Spring Harbor Laboratory.

Oren, A., Gurevich, P., Gemmell, R. T. \& Teske, A. (1995). Halobaculum gomorrense gen. nov., sp. nov., a novel extremely halophilic archaeon from the Dead Sea. Int J Syst Bacteriol 45, 747754.

Oren, A., Ventosa, A. \& Grant, W. D. (1997). Proposed minimal standards for description of new taxa in the order Halobacteriales. Int J Syst Bacteriol 47, 233-238.

Oren, A., Arahal, D. R. \& Ventosa, A. (2009). Emended descriptions of genera of the family Halobacteriaceae. Int J Syst Evol Microbiol 59, 637-642.

Saitou, N. \& Nei, M. (1987). The neighbor-joining method: a new method for reconstructing phylogenetic trees. Mol Biol Evol 4, 406425.

Savage, K. N., Krumholz, L. R., Oren, A. \& Elshahed, M. S. (2007). Haladaptatus paucihalophilus gen. nov., sp. nov., a halophilic archaeon isolated from a low-salt, sulfide-rich spring. Int J Syst Evol Microbiol 57, 19-24.

Savage, K. N., Krumholz, L. R., Oren, A. \& Elshahed, M. S. (2008). Halosarcina pallida gen. nov., sp. nov., a halophilic archaeon from a low-salt, sulfide-rich spring. Int J Syst Evol Microbiol 58, 856-860.

Shimane, Y., Hatada, Y., Minegishi, H., Mizuki, T., Echigo, A., Miyazaki, M., Ohta, Y., Usami, R., Grant, W. D. \& Horikoshi, K. (2010). Natronoarchaeum mannanilyticum gen. nov., sp. nov., an aerobic, extremely halophilic archaeon isolated from commercial salt. Int $J$ Syst Evol Microbiol 60, 2529-2534.

Stackebrandt, E. \& Goebel, B. M. (1994). Taxonomic note: a place for DNA-DNA reassociation and 16S rRNA sequence analysis in the present species definition in bacteriology. Int J Syst Bacteriol 44, 846849. 